\title{
Wearable Antenna Measurements in Vicinity of Human Body
}

\author{
Albert Sabban \\ Electrical Engineering Department, Ort Braude College, Karmiel, Israel \\ Email: sabban@netvision.net.il
}

Received 17 May 2016; accepted 27 June 2016; published 30 June 2016

Copyright (C) 2016 by author and Scientific Research Publishing Inc.

This work is licensed under the Creative Commons Attribution International License (CC BY). http://creativecommons.org/licenses/by/4.0/

(c) (i) Open Access

\section{Abstract}

This paper presents measurements techniques of wearable antennas and RF medical systems in vicinity of human body. The antennas radiation characteristics on human body have been measured by using a phantom. The phantom electrical characteristics represent the human body electrical characteristics. The phantom has a cylindrical shape with a $40 \mathrm{~cm}$ diameter and a length of $1.5 \mathrm{~m}$. The phantom electrical characteristics are similar to the human body electrical characteristics. The antenna under test was placed on the phantom during the measurements of the antennas radiation characteristics. The phantom was employed to compare the electrical performance of several new wearable antennas. The phantom was also employed to measure the electrical performance of several antenna belts in vicinity of human body. The results of antenna with thinner belt are better than the results of the same antenna array with thicker belt.

\section{Keywords}

Wearable Antennas, Wearable Antenna Measurements, Printed Antennas, Phantom, Wireless Communication

\section{Introduction}

Wearable antennas and wearable systems were presented in books and journals; see [1]-[15]. However, several of the presented wearable antennas were not measured in the vicinity of human body. Moreover, details of measurements in the vicinity of human body are not presented in several of these publications. The antennas radiation characteristics on human body may be measured by using a phantom. The phantom electrical characteristics are similar to the human body electrical characteristics. This paper presents measurements techniques of antennas and RF medical systems in vicinity of human body. Also an automatic RF medical system tester will be presented in this paper. By employing this antenna tester we do not have to connect or disconnect the sensor ca- 
ble from the medical system board. The automatic RF medical system tester may be applied to measurements of wearable wireless communication systems. RF transmission properties of human tissues have been investigated in several articles [8] [9]. Several wearable antennas have been presented in the last decade [10]-[14]. A review of wearable and body mounted antennas designed and developed for various applications at different frequency bands over the last decade can be found in [10]. In [11] meander wearable antennas in close proximity of a human body are presented in the frequency range between $800 \mathrm{MHz}$ and $2700 \mathrm{MHz}$.

\section{Phantom Configuration}

The phantom is fiberglass cylinder with $1.5 \mathrm{~m}$ height and $0.4 \mathrm{~m}$ diameter as shown in Figure 1 . The thickness of the cylinder surface is around $2.5 \mathrm{~mm}$. The phantom contains a mix of water, sugar and salt. The relative concentration of water, sugar and salt determines the electrical characteristics of the phantom environment. A mixture of $55 \%$ water $44 \%$ sugar and $1 \%$ salt presents the electrical characteristics of stomach tissues. The phantom may be used to measure electromagnetic radiation from inside or outside the phantom. The phantom contain a plastic rod with $5 \mathrm{~mm}$ thickness. The position of the plastic rod inside the phantom may be adjusted. The plastic rode may be rotated as shown in Figure 2. A small transmitting antenna may be attached to the plastic rod at different height positions. The antenna may be rotated in the $x-y$ plane.

\section{Measurements of Wearable Antennas}

The electrical characteristics of several wearable antennas were measured by using the phantom. The position of the transmitting antennas along the $\mathrm{z}$ axis and $\mathrm{x}$ axis was varied as listed in tables, $(\mathrm{Z}=0, \mathrm{Z}=-15 \mathrm{~cm}$ and $\mathrm{Z}=$ $15 \mathrm{~cm}$ ). The angular angle of the transmitting antenna was varied from $0^{\circ}$ to $270^{\circ}$. Signal reception levels and immunity to noise was measured for several types of wearable antenna. The antennas electrical performance was

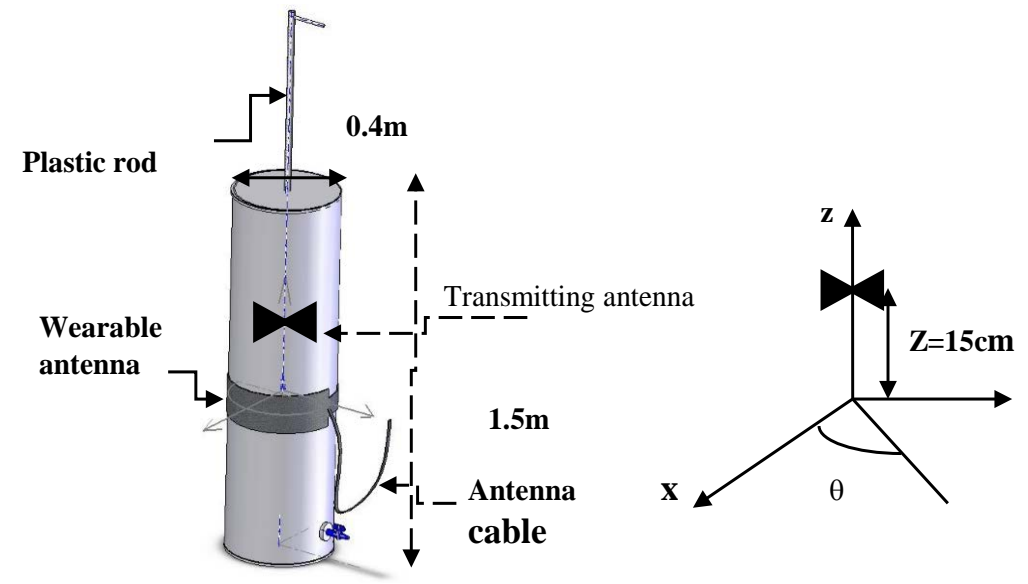

Figure 1. Phantom configuration.

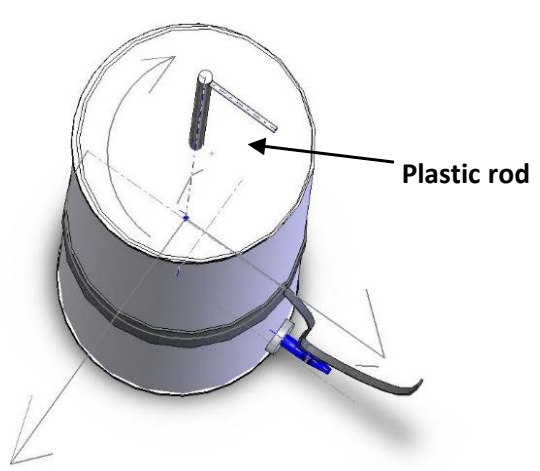

Transmitting antenna

Figure 2. Transmitting antenna rotation. 
compared and the best antenna was chosen according to the system electrical requirements.

\section{Test Procedure and Process}

Test procedure and process is described below.

1) Test procedure

The test checks two parameters of the antennas array:

- Signal reception levels.

- Immunity to noise.

2) Measured antennas

The test checks the following antenna arrays:

- Four sensor antenna array in a belt, antenna in orientations of $+45^{\circ},+45^{\circ},+45^{\circ},-45^{\circ}$.

- Sensor belt with four loop antennas in orientations of $+45^{\circ},+45^{\circ},+45^{\circ},-45^{\circ}$.

- Sensor belt with four antenna in orientations of $+45^{\circ},-45^{\circ},+45^{\circ},-45^{\circ}$.

- Thin belt with four sensor Array in orientations of $+45^{\circ},-45^{\circ},+45^{\circ},-45^{\circ}$.

- Four loop antenna array in a sleeve.

3) Test process

- Place the antenna array on the phantom as shown in the figure and connect to the recorder.

- Signal reception levels.

- Place the transmitter in the phantom in the following coordinates, 5 minutes per each location.

- $\mathrm{Z}$ values: from $-15 \mathrm{~cm}$ to $+15 \mathrm{~cm}$ in $15 \mathrm{~cm}$ increments, 0 being the level of the antennas center.

- $\mathrm{X}$ values: from $-5 \mathrm{~cm}$ to $-20 \mathrm{~cm}$ in $15 \mathrm{~cm}$ increments, 0 being the container's wall where the antennas are attached.

- $\theta$ values: from $0^{\circ}$ to $270^{\circ}$ in $90^{\circ}$ increments, $0^{\circ}$ being perpendicular to the middle of the antennas set.

4) Immunity to noise

Place the transmitter outside the phantom in the following coordinates, 5 minutes per each location:

- Z values: from $-40 \mathrm{~cm}$ to $+40 \mathrm{~cm}$ in $10 \mathrm{~cm}$ increments, 0 being the level of the antennas center.

- X values: $100 \mathrm{~cm}$ from container's wall $\theta$ values: from $0^{\circ}$ to $270^{\circ}$ in $90^{\circ}$ increments, $0^{\circ}$ being perpendicular to the middle of the antennas set.

\section{Measurements Results of Wearable Antennas}

Measurements of five antenna array configuration was measured. For all the configurations the lower measured signal level was when the transmitting antenna is located at $\mathrm{z}=15 \mathrm{~cm}$ and $\mathrm{x}=-5 \mathrm{~cm}$. For all the configurations the higher measured signal level was when the transmitting antenna is located at $\mathrm{z}=0 \mathrm{~cm}$ and $\mathrm{x}=-5 \mathrm{~cm}$.

\subsection{Measurements of Antenna Array 1}

The measured antenna consists of four loop antennas with a tuning capacitor as shown in Figure 3. The loop antenna are printed on FR4 substrate with dielectric constant of $4.8 \mathrm{~mm}$ and $0.25 \mathrm{~mm}$ thickness. The loop radiators orientations are, $+45^{\circ},-45^{\circ},-45^{\circ},-45^{\circ}$. The antennas was inserted in a thin belt. Measurements results of antenna number 1 are listed in Table 1.

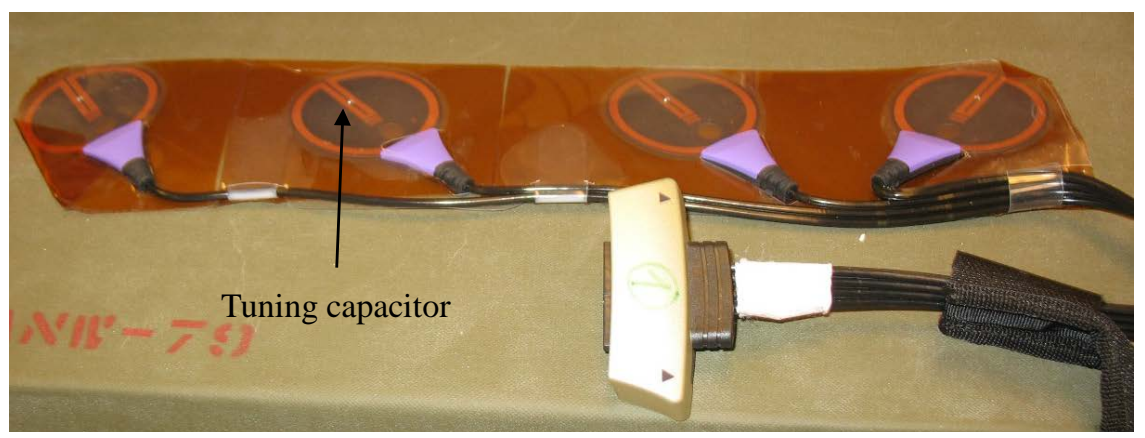

Figure 3. Sensor belt with four antennas in orientations of $+45^{\circ},+45^{\circ},+45^{\circ},-45^{\circ}$. 
Table 1. Measurements of Antenna 1.

\begin{tabular}{|c|c|c|c|c|}
\hline Antenna1 (X cm, Z cm) & \multicolumn{4}{|c|}{ Angle $\theta$} \\
\hline $\mathrm{Z}=0 \mathrm{~cm}$ & $0^{\circ}$ & $90^{\circ}$ & $180^{\circ}$ & $270^{\circ}$ \\
\hline Signal level (dB) $X=-5, Z=0$ & -60 & -63 & -81 & -65 \\
\hline Signal level (dB) $X=-20, Z=0$ & -78 & -70 & -65 & -74 \\
\hline \multicolumn{5}{|l|}{$\mathrm{Z}=15 \mathrm{~cm}$} \\
\hline Signal level (dB) $X=-5, Z=15$ & -81 & -89 & -83 & -82 \\
\hline Signal level (dB) $X=-20, Z=15$ & -86 & -89 & -81 & -85 \\
\hline \multicolumn{5}{|l|}{$\mathrm{Z}=-15 \mathrm{~cm}$} \\
\hline Signal level (dB) $X=-5, Z=-15$ & -70 & -76 & -81 & -68 \\
\hline Signal level (dB) $X=-20, Z=-15$ & -79 & -64 & -74 & -81 \\
\hline Noise test & \multicolumn{4}{|c|}{ Angle $\theta$} \\
\hline $\mathrm{Z}=0 \mathrm{~cm}$ & $0^{\circ}$ & $90^{\circ}$ & $180^{\circ}$ & $270^{\circ}$ \\
\hline Signal level (dB) & -72 & -74 & -74 & -74 \\
\hline Noise level (dB) & -95 & -95 & -95 & -95 \\
\hline \multicolumn{5}{|l|}{$\mathrm{Z}=40 \mathrm{~cm}$} \\
\hline Signal level (dB) & -72 & -74 & -74 & -74 \\
\hline Noise level (dB) & -88 & -88 & -88 & -88 \\
\hline \multicolumn{5}{|l|}{$\mathrm{Z}=-40 \mathrm{~cm}$} \\
\hline Signal level (dB) & -72 & -74 & -74 & -74 \\
\hline Noise level (dB) & -94 & -93 & -94 & -95 \\
\hline
\end{tabular}

\subsection{Measurements of Antenna Array 2}

The measured antenna consists of four loop antennas without a tuning capacitor as shown in Figure 4. The loop radiators orientations are, $+45^{\circ},-45^{\circ},-45^{\circ},-45^{\circ}$. The antennas was inserted in a thin belt. Measurements results of antenna number 1 are listed in Table 2.

\subsection{Measurements of Antenna Array 3}

The measured antenna consists of four tuned loop antennas with a tuning capacitor as shown in Figure 5. The loop radiators orientations are, $+45^{\circ},-45^{\circ},+45^{\circ},-45^{\circ}$. The antennas was inserted in a belt. Measurements results of antenna number 3 are listed in Table 3.

\subsection{Measurements of Antenna Array 4 in a Thinner Belt}

The measured antenna consists of four loop antennas with a tuning capacitor as shown in Figure 6. The loop radiators orientations are, $+45^{\circ},-45^{\circ},+45^{\circ},-45^{\circ}$. The antennas was inserted in a thinner belt. Measurements results of antenna number 4 are listed in Table 4.

\subsection{Measurements of Antenna Array 5}

The measured antenna consists of four loop antennas without a tuning capacitor inserted in a sleeve, as shown in Figure 7. The sleeve improves the antenna VSWR from 4:1 to 2:1. The loop radiators orientations are, $\left(90^{\circ}, 90^{\circ}\right.$, $90^{\circ}, 90^{\circ}$ ). The antennas was inserted in a thin sleeve.

Measurements results of antenna number 5 are listed in Table 5. 


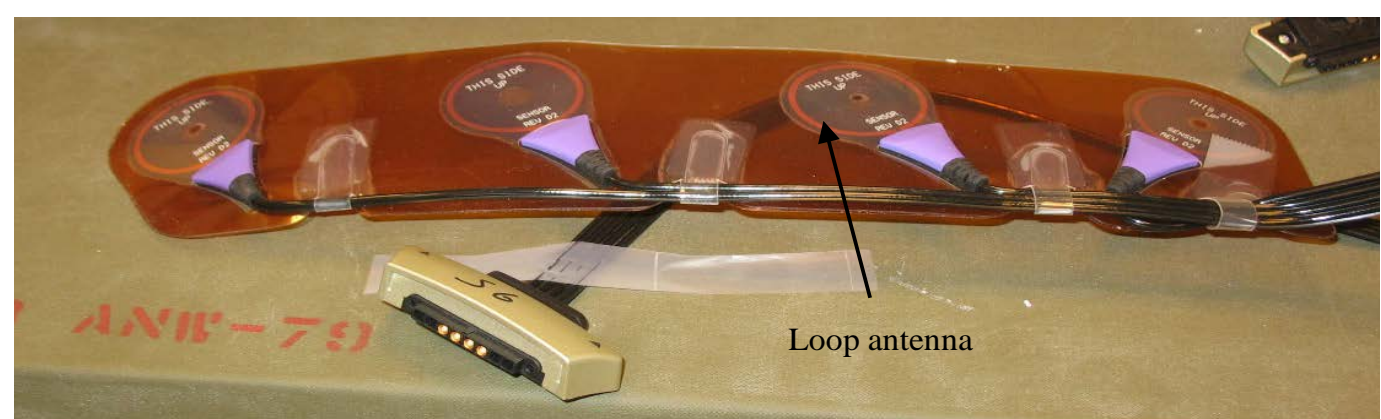

Figure 4. Sensor belt with four antennas in orientations of $+45^{\circ},+45^{\circ},+45^{\circ},-45^{\circ}$ without tuning capacitor.

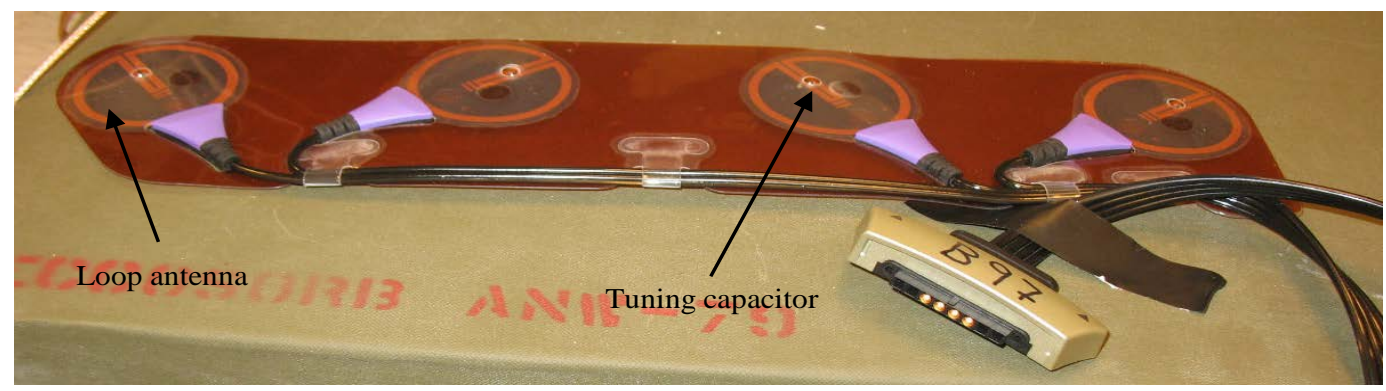

Figure 5. Sensor belt with four antennas in orientations of $+45^{\circ},-45^{\circ},+45^{\circ},-45^{\circ}$.

Table 2. Measurements of Antenna 2.

\begin{tabular}{|c|c|c|c|c|}
\hline Antenna 1 (X cm, Z cm) & \multicolumn{4}{|c|}{ Angle $\theta$} \\
\hline $\mathrm{Z}=0 \mathrm{~cm}$ & $0^{\circ}$ & $90^{\circ}$ & $180^{\circ}$ & $270^{\circ}$ \\
\hline Signal level (dB) $X=-5, Z=0$ & -63 & -70 & -82 & -72 \\
\hline Signal level (dB) $X=-20, Z=0$ & -84 & -66 & -66 & -79 \\
\hline \multicolumn{5}{|l|}{$\mathrm{Z}=15 \mathrm{~cm}$} \\
\hline Signal level (dB) $X=-5, Z=15$ & -82 & -93 & -90 & -84 \\
\hline Signal level (dB) X = -20, Z = 15 & -88 & -83 & -79 & -90 \\
\hline \multicolumn{5}{|l|}{$\mathrm{Z}=-15 \mathrm{~cm}$} \\
\hline Signal level (dB) $X=-5, Z=-15$ & -74 & -82 & -85 & -92 \\
\hline Signal level (dB) $X=-20, Z=-15$ & -86 & -70 & -77 & -81 \\
\hline Noise test & \multicolumn{4}{|c|}{ Angle $\theta$} \\
\hline $\mathrm{Z}=0 \mathrm{~cm}$ & $0^{\circ}$ & $90^{\circ}$ & $180^{\circ}$ & $270^{\circ}$ \\
\hline Signal level (dB) & -67 & -69 & -72 & -68 \\
\hline Noise level (dB) & -85 & -85 & -86 & -85 \\
\hline \multicolumn{5}{|l|}{$\mathrm{Z}=40 \mathrm{~cm}$} \\
\hline Signal level (dB) & -66 & -69 & -72 & -68 \\
\hline Noise level (dB) & -80 & -83 & -86 & -85 \\
\hline \multicolumn{5}{|l|}{$\mathrm{Z}=-40 \mathrm{~cm}$} \\
\hline Signal level (dB) & -68 & -69 & -72 & -69 \\
\hline Noise level (dB) & -84 & -82 & -83 & -83 \\
\hline
\end{tabular}


Table 3. Measurements of Antenna 3.

\begin{tabular}{|c|c|c|c|c|}
\hline Antenna 1 (X cm, Z cm) & \multicolumn{4}{|c|}{ Angle $\theta$} \\
\hline $\mathrm{Z}=0 \mathrm{~cm}$ & $0^{\circ}$ & $90^{\circ}$ & $180^{\circ}$ & $270^{\circ}$ \\
\hline Signal level (dB) $X=-5, Z=0$ & -63 & -63 & -82 & -69 \\
\hline Signal level (dB) $X=-20, Z=0$ & -83 & -70 & -68 & -76 \\
\hline \multicolumn{5}{|l|}{$\mathrm{Z}=15 \mathrm{~cm}$} \\
\hline Signal level (dB) $X=-5, Z=15$ & -85 & -86 & -85 & -86 \\
\hline Signal level (dB) $X=-20, Z=15$ & -89 & -88 & -86 & -85 \\
\hline \multicolumn{5}{|l|}{$\mathrm{Z}=-15 \mathrm{~cm}$} \\
\hline Signal level $(\mathrm{dB}) \mathrm{X}=-5, \mathrm{Z}=-15$ & -72 & -79 & -83 & -74 \\
\hline Signal level (dB) $X=-20, Z=-15$ & -85 & -69 & -77 & -82 \\
\hline Noise test & \multicolumn{4}{|c|}{ Angle $\theta$} \\
\hline $\mathrm{Z}=0 \mathrm{~cm}$ & $0^{\circ}$ & $90^{\circ}$ & $180^{\circ}$ & $270^{\circ}$ \\
\hline Signal level (dB) & -68 & -70 & -76 & -70 \\
\hline Noise level (dB) & -91 & -91 & -92 & -92 \\
\hline \multicolumn{5}{|l|}{$\mathrm{Z}=40 \mathrm{~cm}$} \\
\hline Signal level (dB) & -68 & -70 & -76 & -70 \\
\hline Noise level (dB) & -90 & -88 & -90 & -88 \\
\hline \multicolumn{5}{|l|}{$\mathrm{Z}=-40 \mathrm{~cm}$} \\
\hline Signal level (dB) & -68 & -70 & -76 & -70 \\
\hline Noise level (dB) & -89 & -87 & -90 & -87 \\
\hline
\end{tabular}

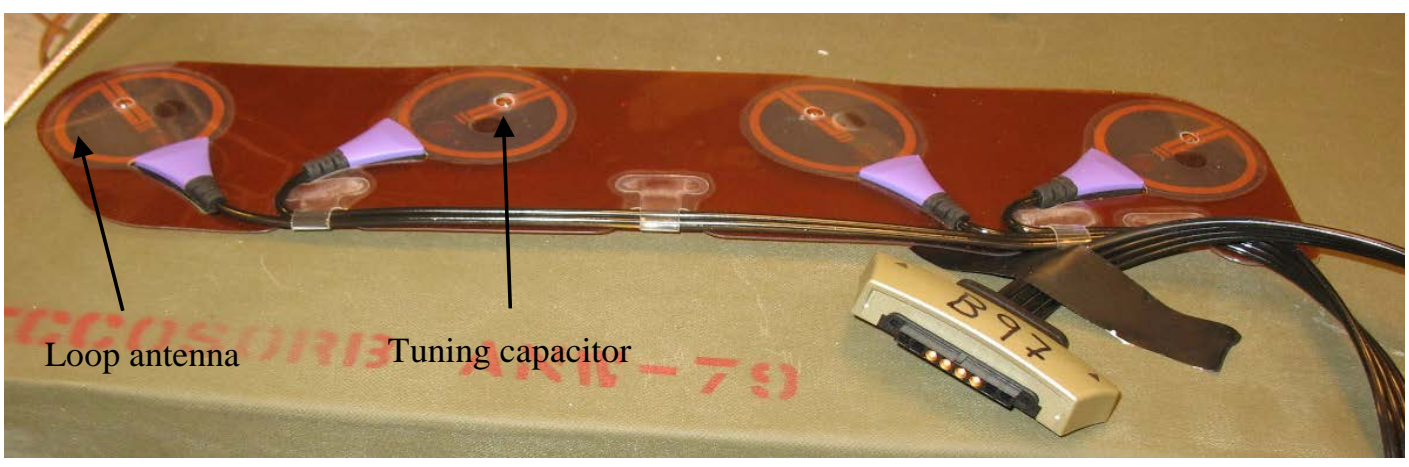

Figure 6. Four antennas in orientations of $+45^{\circ},-45^{\circ},+45^{\circ},-45^{\circ}$, in a thinner belt.

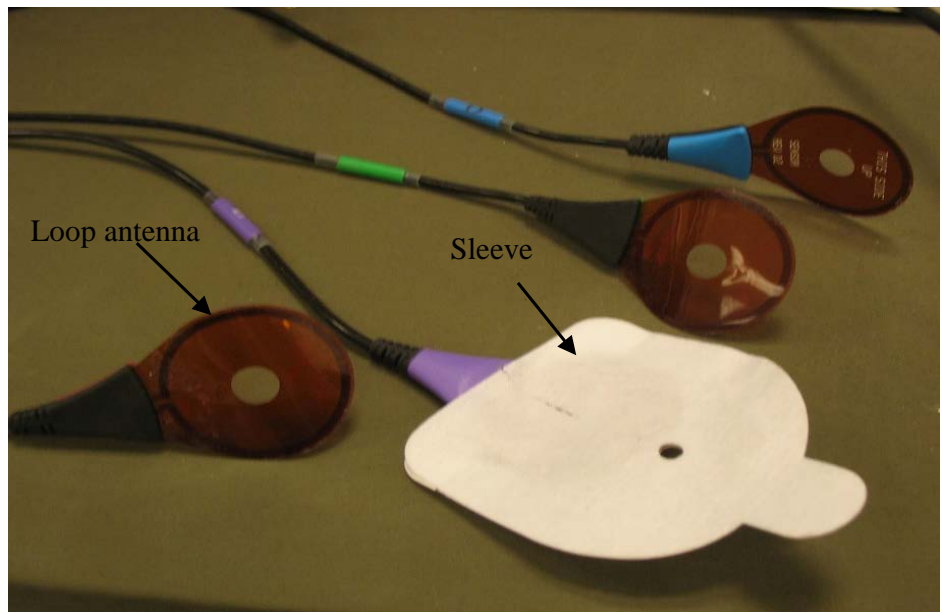

Figure 7. Four loop antennas in a sleeve, radiators orientations are $\left(90^{\circ}, 90^{\circ}, 90^{\circ}, 90^{\circ}\right)$. 
Table 4. Measurements of Antenna 4.

\begin{tabular}{|c|c|c|c|c|}
\hline Antenna 1 (X cm, Z cm) & \multicolumn{4}{|c|}{ Angle $\theta$} \\
\hline $\mathrm{Z}=0 \mathrm{~cm}$ & $0^{\circ}$ & $90^{\circ}$ & $180^{\circ}$ & $270^{\circ}$ \\
\hline Signal level (dB) $X=-5, Z=0$ & -61 & -62 & -81 & -63 \\
\hline Signal level $(\mathrm{dB}) \mathrm{X}=-20, \mathrm{Z}=0$ & -79 & -69 & -67 & -73 \\
\hline \multicolumn{5}{|l|}{$\mathrm{Z}=15 \mathrm{~cm}$} \\
\hline Signal level $(\mathrm{dB}) \mathrm{X}=-5, \mathrm{Z}=15$ & -86 & -88 & -88 & -83 \\
\hline Signal level $(\mathrm{dB}) \mathrm{X}=-20, \mathrm{Z}=15$ & -90 & -84 & -82 & -86 \\
\hline \multicolumn{5}{|l|}{$\mathrm{Z}=-15 \mathrm{~cm}$} \\
\hline Signal level (dB) $X=-5, Z=-15$ & -70 & -81 & -82 & -67 \\
\hline Signal level (dB) $X=-20, Z=-15$ & -80 & -67 & -74 & -81 \\
\hline Noise test & \multicolumn{4}{|c|}{ Angle $\theta$} \\
\hline $\mathrm{Z}=0 \mathrm{~cm}$ & $0^{\circ}$ & $90^{\circ}$ & $180^{\circ}$ & $270^{\circ}$ \\
\hline Signal level (dB) & -70 & -70 & -76 & -70 \\
\hline Noise level (dB) & -95 & -95 & -95 & -95 \\
\hline \multicolumn{5}{|l|}{$\mathrm{Z}=40 \mathrm{~cm}$} \\
\hline Signal level (dB) & -70 & -70 & -76 & -70 \\
\hline Noise level (dB) & -92 & -92 & -91 & -92 \\
\hline \multicolumn{5}{|l|}{$\mathrm{Z}=-40 \mathrm{~cm}$} \\
\hline Signal level (dB) & -70 & -70 & -76 & -70 \\
\hline Noise level (dB) & -92 & -92 & -91 & -92 \\
\hline
\end{tabular}

Table 5. Measurements of Antenna 5.

\begin{tabular}{|c|c|c|c|c|}
\hline \multirow{2}{*}{$\begin{array}{c}\text { Antenna } 1(\mathrm{X} \mathrm{cm}, \mathrm{Z} \mathrm{cm}) \\
\mathrm{Z}=0 \mathrm{~cm}\end{array}$} & \multicolumn{4}{|c|}{ Angle $\theta$} \\
\hline & $0^{\circ}$ & $90^{\circ}$ & $180^{\circ}$ & $270^{\circ}$ \\
\hline Signal level (dB) $X=-5, Z=0$ & -67 & -52 & -58 & -60 \\
\hline Signal level (dB) $X=-20, Z=0$ & -68 & -70 & -77 & -78 \\
\hline \multicolumn{5}{|l|}{$\mathrm{Z}=15 \mathrm{~cm}$} \\
\hline Signal level $(d B) X=-5, Z=15$ & -90 & -86 & -92 & -90 \\
\hline Signal level (dB) $X=-20, Z=15$ & -84 & -86 & -90 & -86 \\
\hline \multicolumn{5}{|l|}{$\mathrm{Z}=-15 \mathrm{~cm}$} \\
\hline Signal level $(\mathrm{dB}) \mathrm{X}=-5, \mathrm{Z}=-15$ & -85 & -90 & -85 & -92 \\
\hline Signal level (dB) $X=-20, Z=-15$ & -90 & -85 & -75 & -78 \\
\hline Noise test & \multicolumn{4}{|c|}{ Angle $\theta$} \\
\hline $\mathrm{Z}=0 \mathrm{~cm}$ & $0^{\circ}$ & $90^{\circ}$ & $180^{\circ}$ & $270^{\circ}$ \\
\hline Signal level (dB) & -70 & 70 & -70 & -70 \\
\hline Noise level (dB) & -90 & -90 & -90 & -90 \\
\hline \multicolumn{5}{|l|}{$\mathrm{Z}=40 \mathrm{~cm}$} \\
\hline Signal level (dB) & -72 & -72 & -72 & -72 \\
\hline Noise level (dB) & -90 & -90 & -90 & -90 \\
\hline \multicolumn{5}{|l|}{$Z=-40 \mathrm{~cm}$} \\
\hline Signal level (dB) & -73 & -73 & -73 & -73 \\
\hline Noise level (dB) & -90 & -90 & -90 & -90 \\
\hline
\end{tabular}




\section{Conclusion}

Best results are achieved with the first antenna with tuning capacitor antennas in orientations of $+45^{\circ},+45^{\circ},+45^{\circ}$, $-45^{\circ}$. The results of antenna number 4 with thinner belt are better than the results of the same antenna array with thicker belt. For all the configurations the higher measured signal level was when the transmitting antenna is located at $\mathrm{z}=0 \mathrm{~cm}$ and $\mathrm{x}=-5 \mathrm{~cm}$. For all the configurations the lower measured signal level was when the transmitting antenna is located at $\mathrm{z}=15 \mathrm{~cm}$ and $\mathrm{x}=-5 \mathrm{~cm}$. The effect of the antenna location on the human body should be considered in the antenna design process.

\section{References}

[1] James, J.R., Hall, P.S. and Wood, C. (1981) Microstrip Antenna Theory and Design.

[2] Sabban, A. and Gupta, K.C. (1991) Characterization of Radiation Loss from Microstrip Discontinuities Using a Multiport Network Modeling Approach. IEEE Transactions on Microwave Theory and Techniques, 39, 705-712. http://dx.doi.org/10.1109/22.76436

[3] Sabban, A. (1983) A New Wideband Stacked Microstrip Antenna. IEEE Antenna and Propagation Symposium, Houston, June 1983.

[4] Sabban, A. and Navon, E. (1983) A mm-Waves Microstrip Antenna Array. IEEE Symposium, Tel-Aviv, March 1983.

[5] Kastner, R., Heyman, E. and Sabban, A. (1988) Spectral Domain Iterative Analysis of Single and Double-Layered Microstrip Antennas Using the Conjugate Gradient Algorithm. IEEE Transactions on Antennas and Propagation, 36, 1204-1212. http://dx.doi.org/10.1109/8.8596

[6] Sabban, A. (1981) Wideband Microstrip Antenna Arrays. IEEE Antenna and Propagation Symposium MELCOM, TelAviv.

[7] Sabban, A. (2011) Microstrip Antenna Arrays. Microstrip Antennas. In: Nasimuddin, N., Ed., InTech, 361-384. http://www.intechopen.com/articles/show/title/microstrip-antenna-arrays http://dx.doi.org/10.5772/14394

[8] Chirwa, L.C., Hammond, P.A., Roy, S. and Cumming, D.R.S. (2003) Electromagnetic Radiation from Ingested Sources in the Human Intestine between $150 \mathrm{MHz}$ and 1.2 GHz. IEEE Transactions on Biomedical Engineering, 50, 484-492. http://dx.doi.org/10.1109/TBME.2003.809474

[9] Werber, D., Schwentner, A. and Biebl, E.M. (2006) Investigation of RF Transmission Properties of Human Tissues. Advances in Radio Science, 4, 357-360. http://dx.doi.org/10.5194/ars-4-357-2006

[10] Gupta, B., Sankaralingam, S. and Dhar, S. (2010) Development of Wearable and Implantable Antennas in the Last Decade. 2010 Mediterranean Microwave Symposium (MMS), Guzelyurt, 25-27 August 2010, 251-267. http://dx.doi.org/10.1109/MMW.2010.5605178

[11] Thalmann, T., Popovic, Z., Notaros, B.M. and Mosig, J.R. (2009) Investigation and Design of a Multi-Band Wearable Antenna. 3rd European Conference on Antennas and Propagation, EuCAP, 462-465.

[12] Salonen, P., Rahmat-Samii, Y. and Kivikoski, M. (2004) Wearable Antennas in the Vicinity of Human Body. IEEE Antennas and Propagation Society International Symposium, 1, 467-470. http://dx.doi.org/10.1109/aps.2004.1329675

[13] Kellomaki, T., Heikkinen, J. and Kivikoski, M. (2006) Wearable Antennas for FM Reception. First European Conference on Antennas and Propagation, EuCAP, Nice, 6-10 November 2006, 1-6. http://dx.doi.org/10.1109/eucap.2006.4585031

[14] Sabban, A. (2009) Wideband Printed Antennas for Medical Applications. APMC 2009 Conference, Singapore, 7-10 December 2009, 393-396. http://dx.doi.org/10.1109/apmc.2009.5384521

[15] Lee, Y. (2003) Antenna Circuit Design for RFID Applications. Microchip Technology Inc., Microchip AN 710c. 


\section{Submit or recommend next manuscript to SCIRP and we will provide best service for you:}

Accepting pre-submission inquiries through Email, Facebook, Linkedin, Twitter, etc A wide selection of journals (inclusive of 9 subjects, more than 200 journals)

Providing a 24-hour high-quality service

User-friendly online submission system

Fair and swift peer-review system

Efficient typesetting and proofreading procedure

Display of the result of downloads and visits, as well as the number of cited articles

Maximum dissemination of your research work

Submit your manuscript at: http://papersubmission.scirp.org/ 